\title{
Political and Cultural Rights in Higher Education Institutes
}

\section{G. Anburaj, T. Mangayarkarasi}

\begin{abstract}
The goal of a human rights-based approach to education is simple that is to assure every child a quality education that respects and help promotes her or his right to dignity and optimum development. However due to the involvement of politics in education for once own greed, and to gain power, has made this right to look down upon. Many recent incidents and cases have shown the pros and cons of the involvement of politics in Education and its effect on the life of students, and their future. Therefore, achieving this goal is, however, enormously more complex. As we all know education is the most powerful tool of mankind. And for students to educate properly and along with getting to learn new things, to grow properly some rights should be provided to them. These rights may be cultural or political and these can be direct or in direct. So in this article we have concentrated on the educational rights of students and then how they face different kinds of difficulties in educational institutes, .we have discussed corruption and reservation in institutes then we have described about recent events related to political and cultural rights of students in educational institutes. This research paper deals all the above said points proven and it has drawn arguments and counter arguments as well.
\end{abstract}

Keywords: dropouts, foundational education, reservation, degradation, quota.

\section{INTRODUCTION}

Education has been formally recognized as a human right since the adoption of the Universal Declaration of Human Rights in 1948.The right to education has for long been recognizedas encompassing not only access to the educational provision, but also to the obligation to eliminate discrimination at all levels of the educational system, and to set the minimum standards and to improve quality of education and resources. Plus, education is necessary for fulfillment of all other civil, cultural, political, economic or social right. This original article has shed the lights on the Perspectives introduced in the Convention of the Rights of the Child Are, Mixing of education with politics, Reservation in Education System, Recent incidents related to politics in educational institutes, and Impact of Politics on higher education institutes, etc.

\section{METHODOLOGY}

The theory of Universalism and Cultural Relativism has been applied throughout this research study since it deals with the human rights, women's rights in particular, cultural rights, solidarity in terms of emancipation, and achieving a

Revised Manuscript Received on January 03, 2020

* Correspondence Author

G.Anburaj*, Englisht, VIT University, Vellore, India. Email: anburaj.g@vit.ac.in

Dr. T. Mangayarkarasi, English, Rani Anna Govt. College for Women, Tirunelveli,India. Email: tmangai09@gmail.com

(C) The Authors. Published by Blue Eyes Intelligence Engineering and Sciences Publication (BEIESP). This is an open access article under the CC BY-NC-ND license (http://creativecommons.org/licenses/by-nc-nd/4.0/) common goal, gender discrimination, and racism. While the theory of universalism is being applied the theory of cultural relativism has become inevitable to this research context. Through these theories it is found that racial deviance and cultural hybridity amongst our Indian society. Nowadays universities have become a place of politicians, leaders, scientists, great economists, astronauts and noble laurates. This attempt of writing an original research paper shed lights and disclosed many areas for further research. The theories which have been applied to Indian context brought out some unexpected results as well moreover it has few limitations. The major limitation of the methodology of this paper is it is applied in Indian higher education institutions and premises solely. Since it is an conceptual attempt theories pertaining to the cultural and political rights have been applied in terms of conceptualization.

\section{Perspectives introduced in the Convention of the Rights} of the Child Are:

The right to education is to be achieved on the basis of equality of opportunity for all irrespective of their gender, race, and caste. Measures must be taken to encourage regular school attendance and reduce the number of dropouts. It is not sufficient just to provide formal education to one. It is also necessary to remove barriers such as poverty and discrimination and to provide the education and resources of sufficient quality to all, in a manner that ensures children can get benefited from it. Discipline must be administered and should be maintained in a manner consistent with both that is the child's dignity and with the right to protection from all forms of violence (home social gender etc.), thus maintaining the respect for the child in the educational environment.

The aims of education are understood and defined in terms of the potential of each child and his inner talent and the scope of the curriculum, clearly stating that education should be more of a preparatory process and interest lightning process for promoting and respecting the human rights. This approach is elaborated in the General Comment on the aims of education, in which the Committee on the Rights of the Child stated and stresses that ARTICLE NUMBER 29 requires the development of education i.e child centered, child friendly, positive surrounding and empowering, and that education goes beyond formal schooling to embrace a wide range of life experiences including struggles and achievements through which positive development and learning will occur. In its General Comment on childhood, the Committee on the Rights of the Child states and tells the right to education begins at birth and encourages the governments to take positive and right measures and provide programmers to enhance parental capacities to promote their children's development and enhance their future.

Blue Eyes Intelligence Engineering \& Sciences Publication (C) Copyright: All rights reserved.

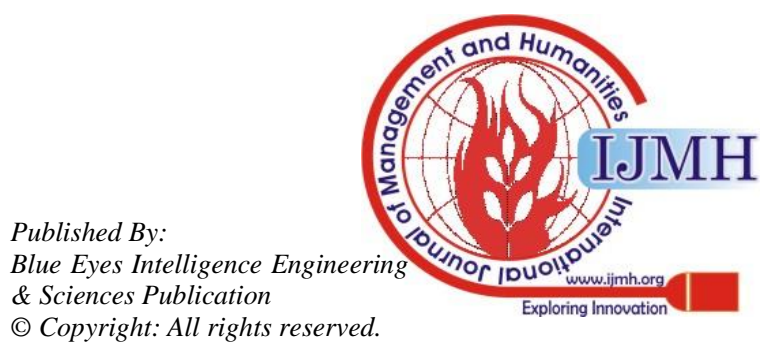




\section{Mixing of education with politics}

India is the largest democracy in the world. It has the many political parties, which take part in election of our country. These elections are held at different level. These elections give a path to various parties which come into our nation's system and exploit it. The problem that we come across on a daily basis and in large scale is political in the education system. Today is the age of innovation and technology. And with this fast developing world, the Indian educational system seems to degrade day by day. Political corruption means using their power given by the nation in a wrong way. The forms of this corruption vary like bribery, extortion, cronyism, nepotism, patronage, graft, etc. Despite growing investment in education, 35\% of its population is still illiterate; less than one fourth of population of Indian students reaches high school. Teaching positions nationwide are vacant, and most of college professors lack either a master's or PhD degree. This is all due to bringing politics in education system in a wrong way. It is due to politics only that half of the rural children could not get higher education. For colleges like ITTs or NITs there is not such a problem but with other colleges and especially private ones, they are filled with political corruption. These private institutes don't take students on the basis of their merit but take on the basis of their status or recommendation given i.e if they are son or daughter of a celebrity or a minister then they get admission, as then these colleges will be able to take as much fee as they want from them.

These private colleges keep more than 50 per cent of their seat reserved for the high class people which can buy these seats. Less than $50 \%$ seats or even less are given on the basis of the merit of the student. It is due these reasons only than rural children are not able to have their education complete especially higher. These institutes also don't care about the kind of education that is being provided to their student i.e they try to save money by hiring less experience or knowledgeable faculties. Its ironical that same thing is with government schools and colleges also but due to different reasons as in these colleges they government is not able to attract good faculty due to their low budget as much of their money is eaten by their department in charge or ministers.

Our country is a developing country and in future it will be still developing only and not a developed nation if our nation's education's system is played is these ways and the bad politics is not removed from it. Government should take action on such practices. The government need to pay attention in this system as education department is one of the foundation of the nation. Politics should not influence it and if it does, it should do in a good way which benefits the system and not rot it.

\section{Reservation in Education System}

In today's world in India reservation is one of the biggest issues, for some people it is a blessing while for it is a curse. This reservation policy was laid by government for the backward classes so that they can become at par with the upper classes and this was good step but at that time because nowadays the lower class people take undue advantage of this policy and get qualified for the good educational institutes like IITs, NITs by just score marks half of the marks of the general category and sometimes even less than that. For Example-in JEE main 2015 that cutoff score for PWD with non-creamy layer was only -23!!This not only leads to degradation of education system of India but also degradation of every sector in India. People getting in from these reservation policies do not know the meaning of knowledge and hard work because they never had to do before. Instead of making the condition of India better this reservation is making the condition of India even worse because now several other minority groups are asking for reservation. This is leading to division of India in small-small categories which is a very serious threat to the future of India since it is generating hatred among the various communities of India and hence decreasing the unity of India. For Example-The Jaats community in Haryana created a massive chaos and burned the buses only because of this reservation. They wanted reservation for them which is totally unjust because they are capable of sending their children to schools and colleges but due to this massive chaos the government had to agree to give them reservation which is of no good use with regard to the education quality of the country.

Nowadays for promoting the education of girls the government, few years back had introduced a new type of quota known as "GIRLS QUOTA" which is again a good step in some backward parts of the country but is a curse for the male general category. So, in a nut shell the conclusion is that nowadays the advantages of this reservation are much less than its disadvantages because due to this reservation the general category people have to suffer. The general category has to work three to four times more to qualify that exam. Due to this reservation the real talented brains of the country are left neglected because they never get a chance to prove themselves because of these reserved class people. This reservation policy which was laid for maintaining the quality has no become one of the biggest reasons for inequality, chaos and injustice which is increasing day by day. So, if we want to have an unbiased nation, we, the people of India should rise together against the reservation because now the meaning of reservation is changed and it has now become like a cancer to our society and our country.

Though there is some relief since some private colleges like VIT, Manipal University etc. do not implement this policy in the entrance exams and due to this the student get a chance to show their talent. According to me, reservation should be given either to those who $r$ financially very weak or to the PWD category because they only deserve this quota because they will surely work hard to qualify the exam since they have no other option and this will lead to a developed India which every Indian citizen wants because this will improve India's condition in every aspect and India will become one of the most powerful country in the world .So let's rise and kill this cancer before this cancer eats up the whole country because if each single person will know the value of hard work and success through it then he/she will surely respect it. So we should start emphasizing the ill effects of this policy from our neighborhood because only by this method slowly and slowly this change will happen since "Charity begins at home" and each of the citizen should take part in this change since "we have to be the change we want to see". So, let's stop thinking and start working since "prevention is better than cure". 


\section{Recent incidents related to politics in educational institutes-}

On 9 February 2016, in Jawaharlal Nehru university in Delhi, some students protested against the hanging or judicial killing of Afzal Guru (a criminal found guilty for the attacks on parliament in 2001).A lot of Kashmiri students and people from inside and outside the campus were to attend the event the meeting. The DSU (Democratic students union) is an ultra-leftist group in jnu that believe in idea of Maoism. This is a small group of some well-read students .they are not indulged in any kind of violent activity at all.so let alone the ABVP (Akhil bharatiya vidhyarthi parishad)two minutes before meeting reached the students and started threatening and intimidating them and organizers.

So many of the Kashmiris started shouting slogans such as "Kashmir hamara hai, saara hamara hai, hamara hi rahega". organizers joined them with the slogan "Humme kya chahiya, azzaadi!" a group of students believed that the Afzal guru was framed in those attacks and hence they started shouting 'Har ghar se Afzal niklega!' and these students were not carrying any arms just they had ideas which were intended to be anti-nationalist .some of the slogans shouted were "Baharat Ki barbadi tak jung rahegi ". The president of jnu was arrested the same day, even though he did not shout these slogans. Some of them were protesting against the death of rohith vemula who committed suicide due to withdrawn of0 his fellowship. Many of them were working on his case and termed it Dalit death. It turned out it wasn't a Dalit death because he was not a Dalit but an OBC. Why did this happen? To know the answer to this question we have to understand the environment in which this happened, actually jnu is university in which students are given enough political rights and freedom, unlike private universities like VIT, in jnu students are allowed to form political groups and they are free to organize political rallies and meetings. Even against the government and university authorities. As so these students are given so many rights these groups sometimes become rivals and just to make the other party look bad they do some kind of activities which leads to controversy. Although the university has provided them right to speech freely it does not mean that they can speak against the government. First of all assembling to celebrate the hanging anniversary of a terrorist stupid thing and if this is not seditious then what is?

The Indian law regarding sedition clearly states that only if a speech incites people to be violent, or take any such action that can be seen as a contravention of laws, it should be considered as punishable. The Constitution draws a clear difference between the advocacy and the incitement. This means that even if any person or any group of individuals' speaks against the state or that state can be violently overthrown it does not count in sedition and the speaking person or group can't be put behind bars. If someone promotes a rivalry between communities or groups on the basis of factors such as religion and race then that act can be considered punishable.

Now how students were affected matters, but on the other hand political leaders are using this incident as an opportunity for pressing the existing government, as it was the PM who was shouting the slogans any anti nationalist slogan shouted inside the boundaries of this country should be unquestionably unacceptable and punishable. But what about the responsibility of these political leaders .So these were some students of a university with some issues in their minds and some ideas which may not be much clear but what is the expected action of the government in such case?. Clearly arresting them is not good option but some good leaders should come forward and conduct debates with students and clear all their minds and resolve their issues and they should be counseled.

\section{Impact of Politics on higher education institutes:}

"No goal is more important or attainable than ensuring access to higher education by removing political barriers". Today politics is creating its impact in every field. It is showing its major impact on students who are having their higher education. The politics put some good impact and bad impact too. The higher educational intuitions are majorly effected by local politics for local bandhs and local political affairs. Due to this the young students bunk the collages and participate in those political affairs which is not very useful to them and even they lose their exams and portions will not be covered too. And some political parties change the syllabus and subjects which bring good fame to their and the other impact were miss guiding and trapping them for their personal offences. And in between to defence them from the opposition party the elected parties will announce some scholarship schemes which is very much useful. And even some political parties will bring some major programs to make the students to participate in some technical and social events which develop the country.

Now a day's some higher educational institutions are started by political leaders. They even use the students to get the majorities and some innovative things like creating some surveys in the public and knowing them and solving their problem which benefit's pubic, political leader and even students. Even due to the impact of politics at present in CBSE schools Sanskrit language made as mandatory as a third language. Earlier German language was considered as third language. This is all because when Modi came into rule he changed to encourage the Indian culture. And also he made yoga as one of subject mandatory to teach as a part of educational system. These all things are due to the power of politics in educational institutes.

And in some institutes if the head of institute was a member of politics then they provide voters cards to the students to vote for them and they use the students for their political purposes and use the students to participate in bandhs and rallies according to their convenient parties. As there were good impacts and bad impacts hope students should select the best ways .and hope the politics and higher education institution together bring India forward in all aspects.

\section{DISCUSSION OF THE RESULT}

The difference in the amount of people who depend on their culture to define how they identify as a person and those who don't is extremely small, with a difference of 3. Due to the cultural dependency of various people, $17.6 \%$ people face conflict due to clashing of ideas, $20.4 \%$ people do not feel comfortable due to the rituals conducted in different cultures, $38.9 \%$ people complained about the Ineffective implementation of an ideas that is needed but not supported by the majority,

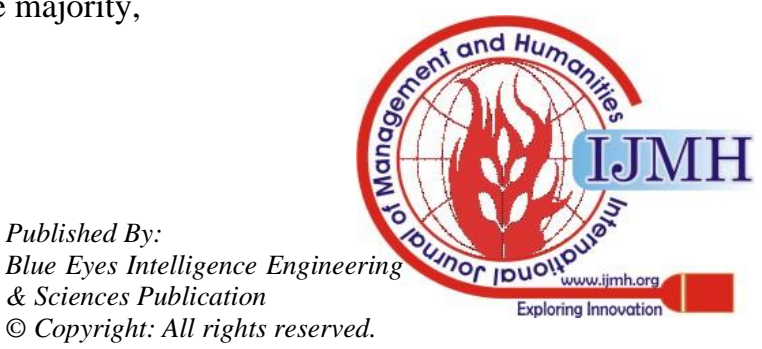


$14.8 \%$ people face problems due to the current government not supporting their cultural beliefs, and $8.3 \%$ people face none of these problems.

Majority of the students studying in India were reluctant little bit in disclosing from group discussions and meetings due to conflict of ideas and beliefs with the support of 56 out of learners. However, 64 have either felt or witnessed somebody else get overshadowed by a person or a group of people who think that they're in a superior position. In this regard, most of the responses what we see from media and social media were extremely positive. $80 \%$ of the people think that the universities promote intercultural education. Moreover $65 \%$ people also supported the idea that intercultural education prepares students for a living a diverse society. When asked whether people feel more at ease using social media to communicate, $55 \%$ people disagreed with it, while the other $45 \%$ agreed that it helped them feel more comfortable.

\section{CONCLUSION}

There is not a discussion on what is or is not human right. Human rights as political norms are dealing mainly with how people should be dealt with by the governments and institutions. Researchers who want to understand that what causes the human rights violations. Their results are typically laid down into specific areas, such as the causes of, genocide, against humanity, and so on. But talking about student's right we can say that in each country different kinds of rights are given to students at different levels of their education. These basically include right to choose their stream, right to stand against if something wrong is happening, right to speech etc. Right to the advertised course content, Right to the advertised level of course instruction, Right to attention to course objectives, Right to uniformity across class sections, Right to learn etc. Are some of the other rights given to students?

\section{REFERENCE}

1. Jerrie Cobb Scott (Editor), Dolores Y. Straker (Editor), Laurie Katz, Affirming Students' Right to their Own Language: Bridging Language Policies and Pedagogical Practices, Routledge; 1 edition; June 2009

2. Stephanie Hinnershitz, Race, Religion, and Civil Rights: Asian Students on the West Coast, 1900-1968 (Asian American Studies Today), Rutgers University Press; September 2010

3. Mark Davies, Malcolm X: The Struggle for Human Rights; Ebook for Students, Ltd. December 2010

4. Thomas Paine, Rights of Man (Penguin Classics), Penguin; Reprint edition; May 1984

5. Patricia H. Hinchey, Student Rights: A Reference Handbook (Contemporary Education Issues), ABC-CLIO Ltd; annotated edition edition; June 2001

6. Subho Chakraborty, Racial Discrimination on International Student; ABC-CLIO Ltd; annotated edition edition; June 2001

7. M. Laxmikanth, Indian Polity 4th Edition; McGraw Hill Education India Private Limited; 4th edition; July 2010

\section{AUTHOR'S PROFILE}

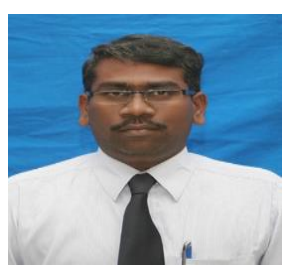

Prof. G. Anburaj is a faculty of English having 17 years teaching experience in various countries like Tanzania, China and India and currently working in VIT University which is one of the world class Universities. He has specialized in ELT and has published more than 23 research papers and original articles in leading national and international Scopus and Non-Scopus indexed journals. He has presented papers at international conferences in many states across India. He is passionate about teaching English to Chinese, Arabs and Africans.

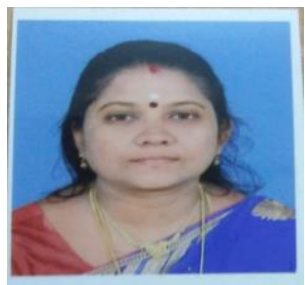

Dr. T. Mangayarkarasi is an Assistant Professor of English in Rani Anna Government College for Women, Tirunelveli and Government Siddha Medical College, Palayamkottai. Having 18 years of teaching experience through various colleges and universities throughout Tamilnadu, She has become one of the eminent research guides in Manonmaniam Sundaranar University. She is also a graduate in Library and Information Science and post graduate in Yoga for Human Excellence. She has organized and participated in various workshops conducted by the government of Tamilnadu. She has co-ordinated 235 hours of Soft Skills Training program conducted by the Government of Tamilnadu for hundreds of Government Arts and Science College's learners. She has been a resource person in literary association meetings, conferences and seminars as well. 